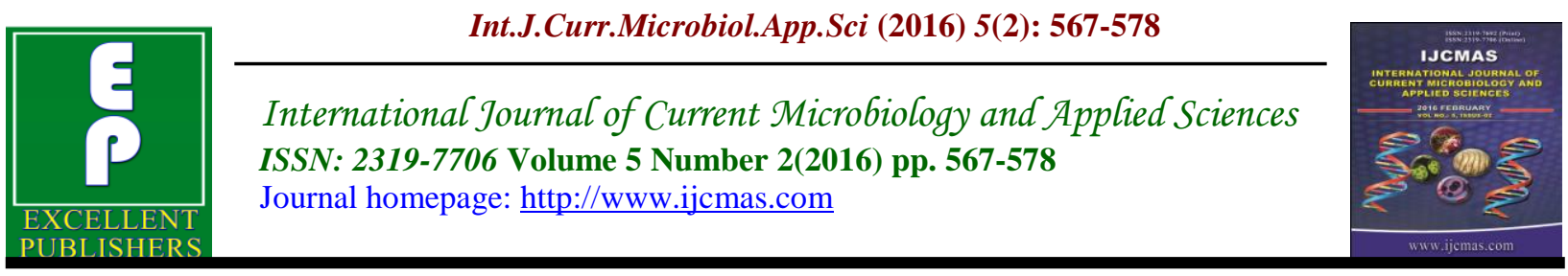

Original Research Article

doi: http://dx.doi.org/10.20546/ijcmas.2016.502.064

\title{
Activity of Purified Bacterial Myrosinase and its Essential Residues
}

\author{
Hamed M. El-Shora*, Ahmed M. El-Shobaky and Maissa M. El-Atrozy \\ Botany Department, Faculty of Science, Mansoura University, Egypt \\ *Corresponding author
}

\begin{abstract}
A B S T R A C T
Keywords

Bacillus

thuringiensis,

Myrosinase,

Characterization,

Essential

residues,

GA3

\section{Article Info}

Accepted:

26 January 2016

Available Online:

10, February 2016

Myrosinase (thioglucoside glucohydrolase or thioglucosidase) (EC 3.2.3.147) hydrolyzes the glucosinolate to thiocyanates, isothiocyanates, epithionitrile, nitriles, oxazolidine-thione. Myrosinase was isolated from Bacillus thuringiensis. The enzyme was partially purified by ammonium sulfate and Sephadex G-200. The specific activity was 64 units mg-1 protein. The optimal $\mathrm{pH}$ and temperature of the enzyme were 8.0 and $50{ }^{\circ} \mathrm{C}$, respectively. The optimal incubation time was $40 \mathrm{~min}$. The chelating agent $\alpha$ - $\alpha$-dipyridyl inhibited the enzyme activity in concentrationdependent manner. Adding Triton $\mathrm{X}-100$ at various concentrations resulted in an increase of the enzyme activity. Diethylpyrocarbonate (DEPC), N-ethylmaleimide (NEM), N-bromosuccinimide (NBS) and phenylglyoxal (PGO) inhibited the enzyme activity at the various tested concentrations and the inhibition was dependent on the concentration of each tested compound. Mercaptoethanol activated the enzyme activity at the tested concentrations 20,40 and $60 \mathrm{mM}$ then the activity declined with increasing the concentration. GA3 as phytohormone activated myrosinase continuously up to $80 \mu \mathrm{mol}$ then declined at $100 \mu \mathrm{mol}$. The thiol compounds L-methionine, N-acetylcysteine, cysteine, thiourea and dithiothreitol (DTT) activated the enzyme and $\mathrm{N}$-acetylcysteine was the best activator.
\end{abstract}

\section{Introduction}

Enzymes are biocatalysts for wide number of chemical reactions. The microbial enzymes are involved in industry and medicine. The microbial enzymes are more stable than those isolated from plants and animals (Buchholz et al., 2012).

Microorganisms represent the best source of enzymes because of two reasons. Firstly, they can be cultured giving large quantities of enzymes in a short time. Secondly, they have susceptibility to gene manipulation and biochemical diversity. The microbial enzymes characterized by their wide-spread with numerous industrial commercial applications. Various industries are looking for new microbial strains to produce various enzymes to fulfill the current enzyme requirements (Cavicchioli et al., 2011, Anbu et al., 2013).

Application of various enzymatic processes in the chemical industry depends mainly on cost competitiveness as well as established 
chemical methods. Among the main advantages of the biotechnological processes compared to well-established chemical processes are lower energy demand, increased product titer, increased catalyst efficiency, less catalyst waste and byproducts, as well as lower volumes of wastewater streams (Buchholz et al., 2012).

In plants, myrosinase (EC 3.2.1.147) is known to be a cytosolic enzyme; however, the cellular organization of the myrosinaseglucosinolate system remains unclear. Brassicales contain a myrosinase enzyme that hydrolyzes glucosinolates to form toxic isothiocyanates, as a defense against bacteria, fungi, insects and herbivores including man (Verkerk et al., 2009). Myrosinase is located in the adjacent phloem parenchyma (Koroleva et al., 2010).

The products of myrosinase action on glucosinolates are used in reducing various types of cancers in human (Dufour et al., 2015), alternative biocidal compounds (Dinkova-Kostova and Kostov, 2012), create several flavors such as isothiocyanate was responsible for the hot flavors of condiments made from mustard and horseradish, and sinigrin are the cause of bitterness of some Brassica vegetables (Van Doorn et al., 1998, Angelino et al., 2015).

Microorganisms including bacteria and fungi have been reported for their glucosinolate-degradation. Among these microorganisms are Lactobacillus agilis strain R16 (Palop et al., 1995), Aspergillus calvatus and Fusarium oxysporum (Smith et al., 1993), Aspergillus sp. NR-4201 (Sakorn et al., 1999) and Aspergillus sp (Rakariyatham et al., 2005). Also, it has also been assayed in bacteria associated with mammal gut microflora (Fahey et al., 2012).

The aim of the present work was to isolate and purify myrosinase from Bacillus thuringiensis. In addition, it aimed to study the biochemical characteristics of the enzyme.

\section{Materials and Methods}

\section{Source of the Enzyme}

Bacillus thuringiensis was the organism used in the isolation, purification of myrosinase and studying the response of the enzyme to various effectors.

\section{Source of the Enzyme}

Bacillus thuringiensis was the organism used in the isolation, purification of glucose isomerase and studying the response of the enzyme to various effectors.

\section{Growth of Bacillus thuringiensis}

The pure culture was inoculated into a 250 $\mathrm{ml}$ conical flask containing $250 \mathrm{ml}$ of culture medium (peptone 1g, yeast extract $0.5 \mathrm{~g}, \mathrm{~K} 2 \mathrm{HPO} 40.3 \mathrm{~g}, \mathrm{MgSO} 4.7 \mathrm{H} 2 \mathrm{O} 1 \mathrm{~g}$, sinigrin $1 \mathrm{~g}$, distilled water $250 \mathrm{ml}, \mathrm{pH} 7.0$ ) followed by incubating at $37{ }^{\circ} \mathrm{C}$ on shaker for $24 \mathrm{~h}$.

\section{Preparation of Myrosinase Extract}

The culture filtrate of Bacillus thuringiensis grown for $72 \mathrm{~h}$ at $37{ }^{\circ} \mathrm{C}$ was obtained by centrifugation at $5000 \mathrm{rpm}$ and used as extract of myrosinase.

\section{Partial Purification of Myrosinase}

The obtained crude extract of myrosinase was precipitated using (NH4)2SO4 with $85 \%$ saturation. It was left at $4^{\circ} \mathrm{C}$ overnight then centrifuged at $6000 \mathrm{rpm}$ for $20 \mathrm{~min}$. The pellet was dissolved in $100 \mathrm{mM}$ borate buffer ( $\mathrm{pH}$ 7.5). The resulting suspension 
was examined for enzyme activity, then subjected to Sephadex G-200.

\section{Assay of Myrosinase}

Myrosinase activity was assayed according to the method of Palmieri et al. (1986). Assays was carried out using $5 \mathrm{mM}$ potassium phosphate buffer ( $\mathrm{pH}$ 7.0), containing $0.5 \mathrm{mM}$ sinigrin, in a total volume of $3 \mathrm{ml}$. The assay buffer was equilibrated at $37{ }^{\circ} \mathrm{C}$. The reaction was initiated by adding of $50 \mu \mathrm{l}$ of enzyme solution. The decrease in the absorbance at $227 \mathrm{~nm}$. The enzyme activity was expressed as $1 \mu \mathrm{mol}$ of sinigrin per min under standard assay conditions. One unit of myrosinase activity was defined as the amount of enzyme that catalyzed the liberation of 1 $\mu$ mol of glucose per min from sinigrin under the above described conditions.

\section{Protein Determination}

Protein concentration was determined spectrophotometrically according to Bradford (1976).

\section{Optimization of $\mathrm{pH}$ and Temperature}

The $\mathrm{pH}$ was optimized using $\mathrm{pH}$ range of 410. The temperature was optimized using temperature range of $10-70{ }^{\circ} \mathrm{C}$. Optimization of the incubation time for the reaction mixture was carried out in the range 10-60 min.

\section{Effect of Effectors and Modifying Agents}

The chelating agent $\alpha$ - $\alpha$-dipyridyl was tested at various concentrations $0.2,0.4,0.6,0.8$ and $1.0 \mathrm{mM}$. Gibbrellic acid (GA3) was tested at 20, 40, 60, 80 and $100 \mu \mathrm{mol}$ TritonX-100 was tested using various concentrations $0.2,0.4,0.6,0.8$ and $1.0 \%$ (v/v). Diethylpyrocarbonate (DEPC), N- bromosuccinimide (NBS) and Nethylmaleimide (NEM) were examined at $1,2,3,4$, and $5 \mathrm{mM}$ in the reaction mixture. Mercaptoethanol was tested at 20, 40, 60, 80 and $100 \mathrm{mM}$. The thiol compounds Lmethionine, N-acetylcysteine, cysteine, thiourea and dithiothreitol (DTT) were tested at $5 \mathrm{mM}$ in the reaction medium.

\section{Results and Discussion}

Myrosinase was purified by $85 \%$ ammonium sulphate precipitation followed by Sephadex G200. The obtained specific activity was 64 units mg-1 protein (Table 1). The enzyme from cauliflower seedlings showed a lower specific activity of 12.71 units/mg protein (Prakash et al., 2013).

\section{Effect of pH on Myrosinase Activity}

The activity was determined at various $\mathrm{pH}$ values $(4,5,6,7,8,9$ and 10). The results in Fig. 1 illustrate that there was a continuous increment in the activity of myrosinase up to $\mathrm{pH} 8.0$ after which the activity declined at $\mathrm{pH} 9$ and 10. It appears that the optimal temperature is 8.0. However, the enzyme from Lepidium latifolium L. (Bhat et al., 2015) and cauliflower seedlings (Prakash et al., 2013) was 6.0. The maximum activity was observed below $\mathrm{pH} 5$ for myrosinase from broccoli (Mahn et al., 2014). The enzyme from horseradish root exhibited high activity at broad $\mathrm{pH}(\mathrm{pH} 5.0-8.0)(\mathrm{Li}$ and Kushad, 2005).

\section{Effect of Temperature on Myrosinase Activity}

The effect of temperature on the enzyme activity was determined at various temperatures $(10,20,30,40,50,60$ and 70 $\left.{ }^{\circ} \mathrm{C}\right)$ was investigated. The results in Fig. 2 show that at the beginning there was a continuous increase in the enzyme activity 
from $10{ }^{\circ} \mathrm{C}$ to $50{ }^{\circ} \mathrm{C}$, then the enzyme activity has reduced at $60{ }^{\circ} \mathrm{C}$ and $70{ }^{\circ} \mathrm{C}$. Thus, the optimal temperature was $50{ }^{\circ} \mathrm{C}$. These results are in harmony with those reported for the enzyme from Lepidium latifolium L. (Bhat et al., 2015) and cauliflower seedlings (Prakash et al., 2013).

Lower optimal temperature $40{ }^{\circ} \mathrm{C}$ was observed for myrosinase from broccoli (Mahn et al., 2014), however the horseradish enzyme exhibited optimal temperature at range of $37-45^{\circ} \mathrm{C}$ ( $\mathrm{Li}$ and Kushad, 2005).

\section{Effect of Incubation Time on Myrosinase Activity}

The effect of incubation time on enzyme activity was investigated at various time intervals (10, 20, 30, 40, 50 and $60 \mathrm{~min})$. The results in Fig. 3 show that by increasing the incubation time there was an increment in myrosinase activity up to 40 min then the activity declined at 50 and $60 \mathrm{~min}$.

\section{Effect of the Chelating Agent $\alpha$ - $\alpha$ - dipyridyl on Myrosinase Activity}

This experiment was carried out to illustrate the effect of $\alpha, \alpha$-dipyridyl as chelating agent on the enzyme activity. This compound was tested at various concentrations $(0.2,0.4$, 0.6, 0.8 and $1.0 \mathrm{mM}$ ). The results in Fig. 4 show that increasing the concentration of $\alpha, \alpha$-dipyridyl resulted in continuous decrease of enzyme activity until it reached 1.8 units only. The inhibition of myrosinase in the present investigation by this compound reveals that this enzyme is metalloenzyme. However, myrosinase from Lepidium sativum seedlings was not inhibited by $\alpha, \alpha$-dipyridyl and phenanthroline (Durham and Poulton., 1990) for the enzyme from Lepidium sativum seedlings.

\section{Effect of Triton $\mathrm{X}-100$ on Myrosinase Activity}

In this experiment the influence of Triton $\mathrm{X}-100$ as a surfactant on the enzyme activity was investigated. The Triton $X-100$ was tested at various concentrations $(0.2$, $0.4,0.6,0.8$ and $1.0 \%(\mathrm{v} / \mathrm{v})$. The results recorded in Fig. 5 show that increasing the concentration of Triton $\mathrm{X}-100$ led to a continuous increase in the enzyme activity. It was noticed that at the higher concentrations 0.8 and $1.0 \% \quad(\mathrm{v} / \mathrm{v})$ the increase in the activity was not remarkable. The activity of myrosinase was increased in the presence of Triton X-100 as non-ionic surfactant in concentration-dependent manner. The enhancement of myrosinase activity by surfactant is consistent with the results for other enzymes (Najafi et al., 2005). Solubilization of enzymes by surfactants may lead to unmasking of the hidden catalytic sites by release of an allosteric inhibitory mechanism or by conformational changes in the molecule which renders the enzyme more active (Mandviwala and Khire, 2000).

\section{Effect of Diethylpyrocarbonate (DEPC) on Myrosinase Activity}

DEPC is a reagent for histidyl group in proteins (El-Shora, et al., 2008). So, to test the effect of DEPC as a histidine reagent it was used at various concentrations $(1,2,3$, 4 , and $5 \mathrm{mM}$ ) in the reaction mixture. The results in Fig. 6 show that the enzyme activity decreased continuously in a concentration-dependent manner. At $6 \mathrm{mM}$ the enzyme activity was 1.6 units $\mathrm{mg}-1$ protein presenting $11.7 \%$ relative activity. The inhibition of myrosinase by DEPC indicates the necessity of histidyl group for enzyme catalysis. These results are in harmony with those reported previously by Durham and Poulton (1990) for the enzyme from Lepidium sativum seedlings. 
Int.J.Curr.Microbiol.App.Sci (2016) 5(2): 567-578
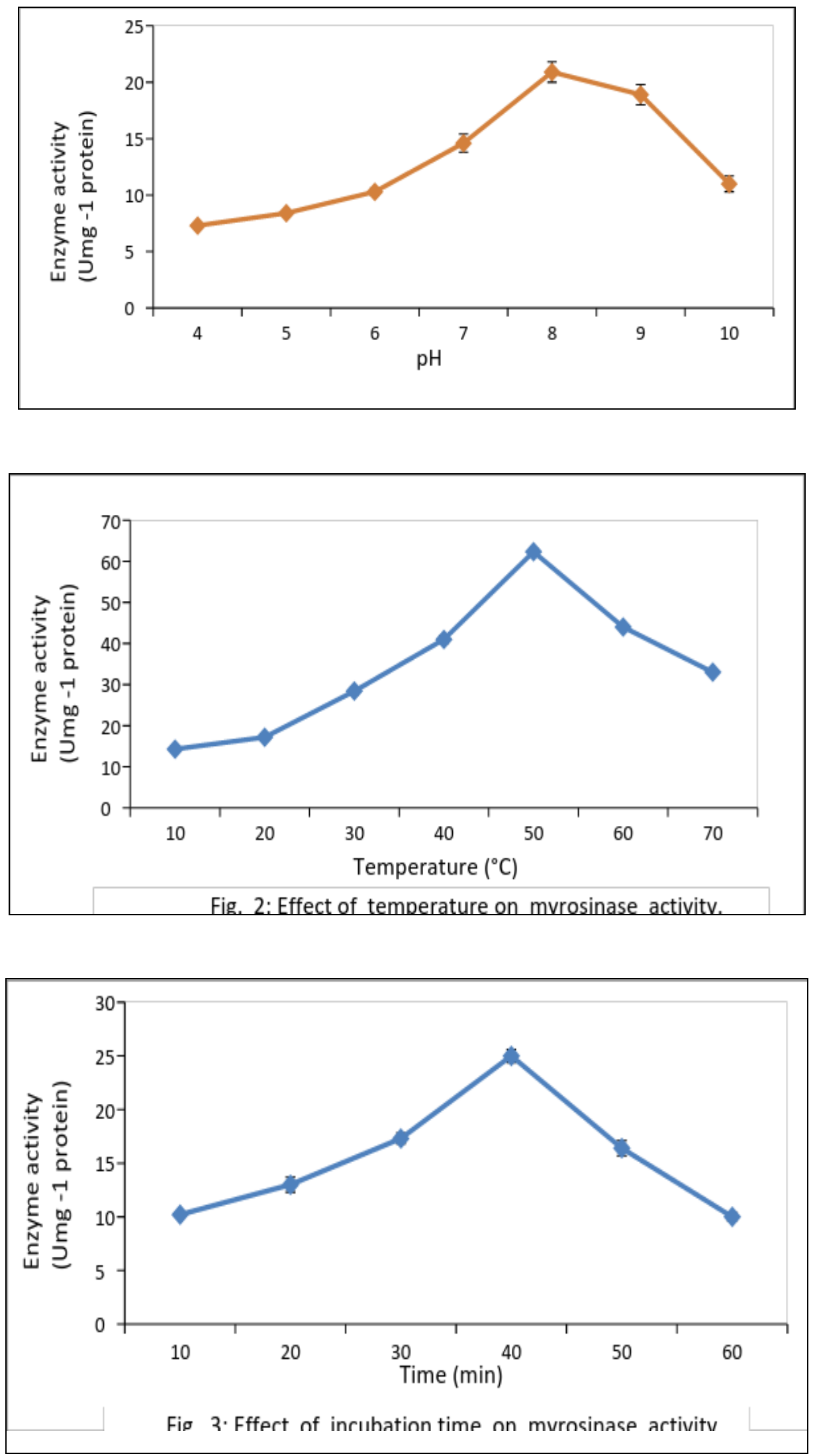

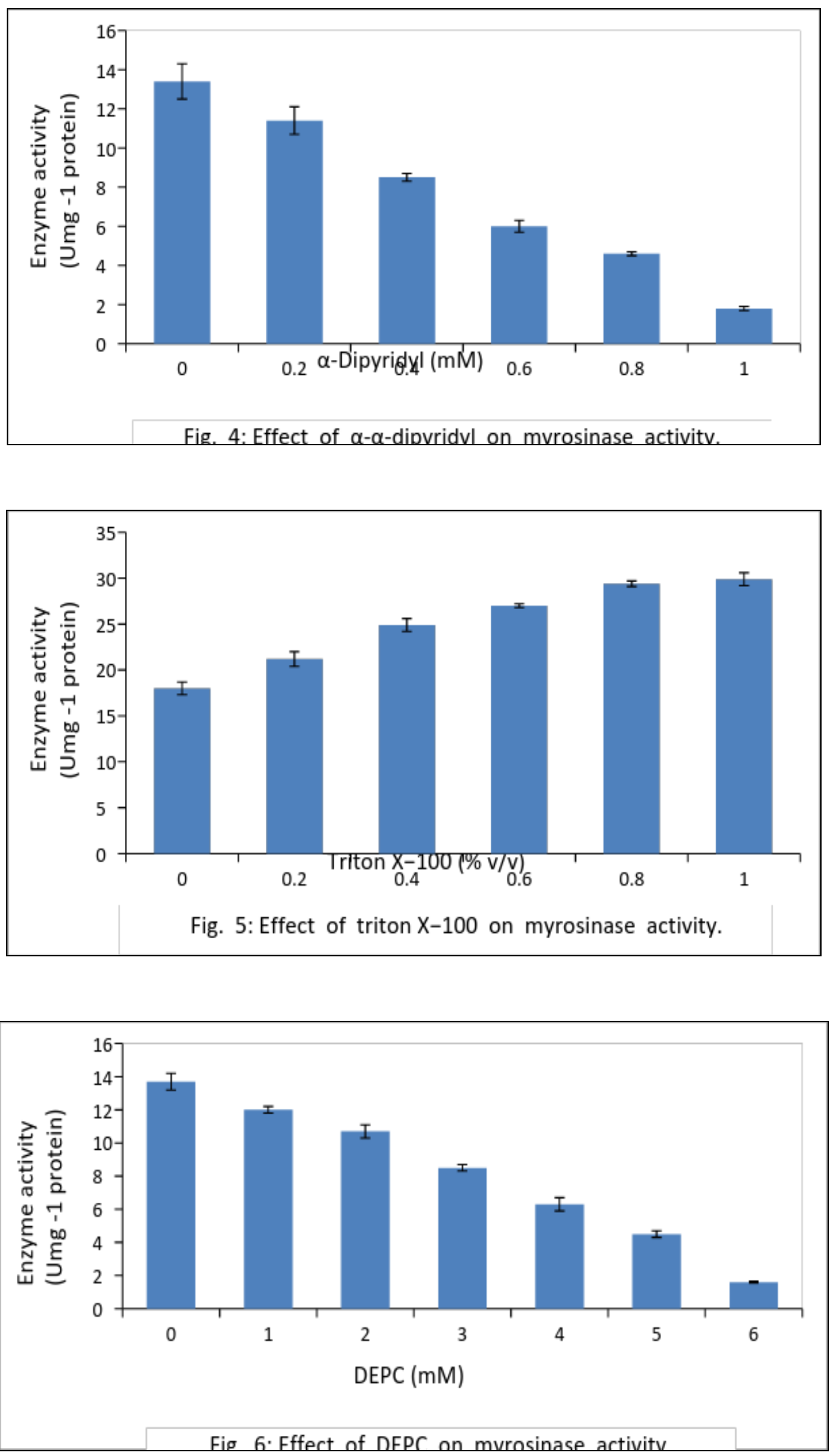

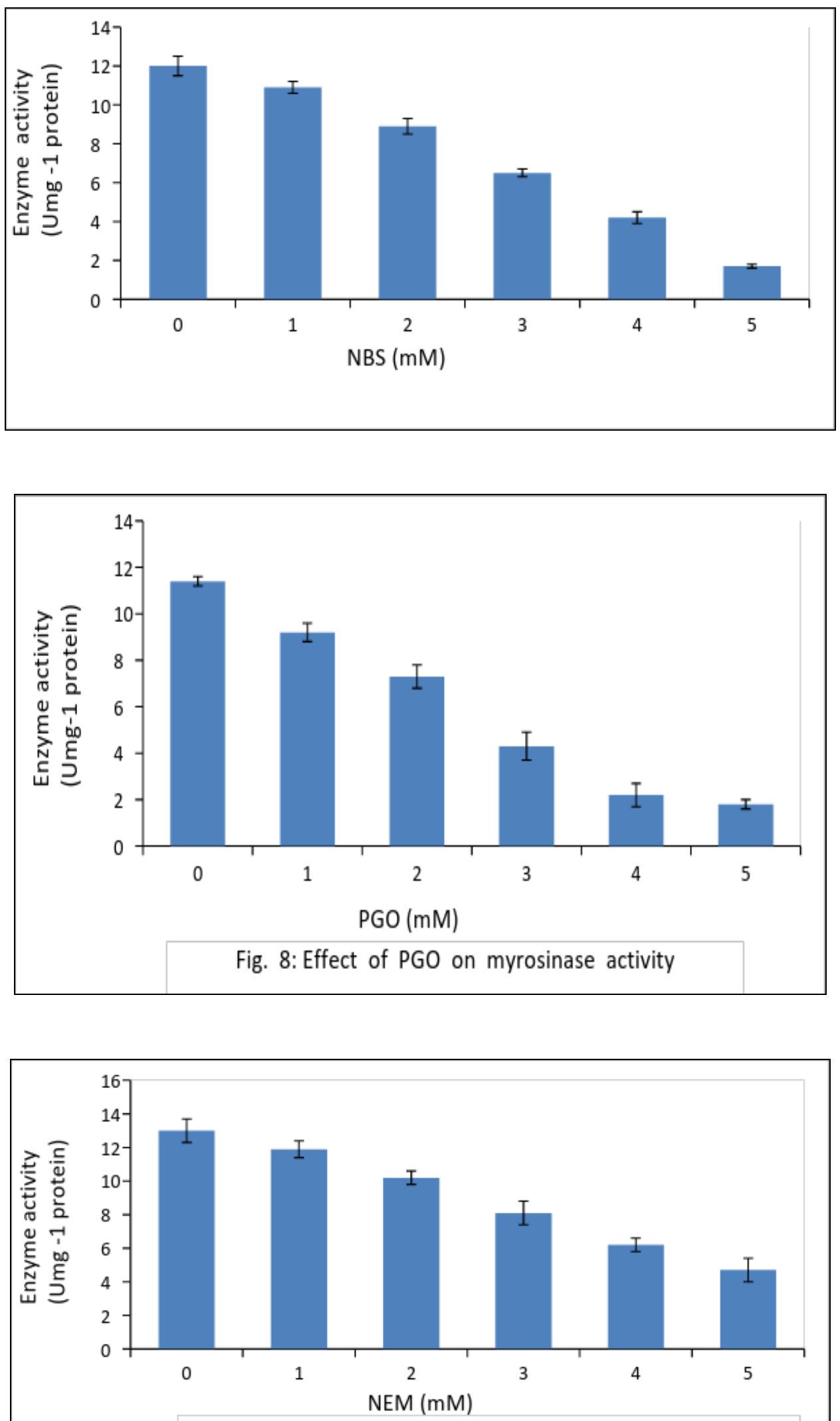

Fig. 9: Effect of NEM on myrosinase activity 
Int.J.Curr.Microbiol.App.Sci (2016) 5(2): 567-578
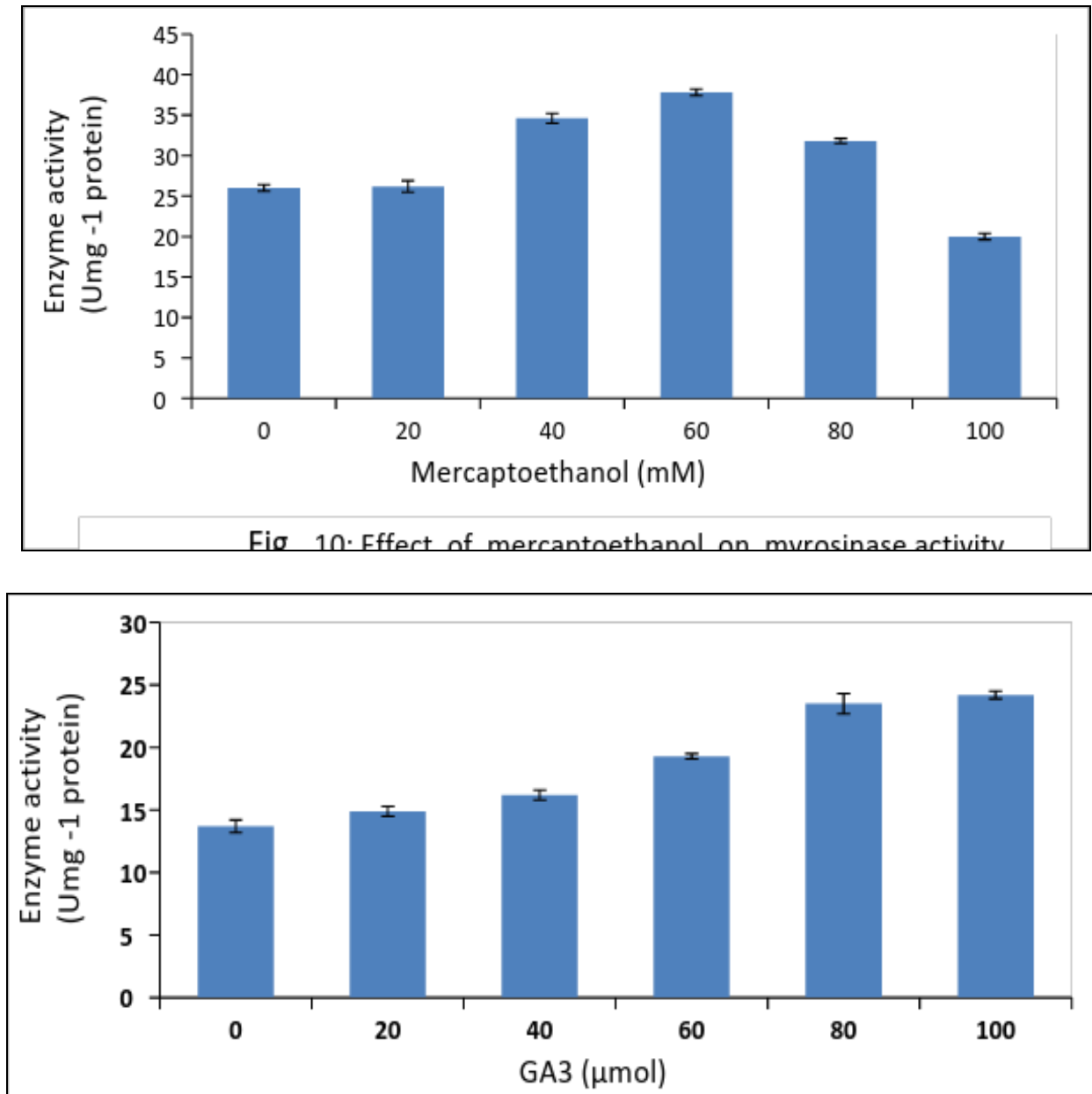

Fig. 11: Effect of GA3 on myrosinase activity.

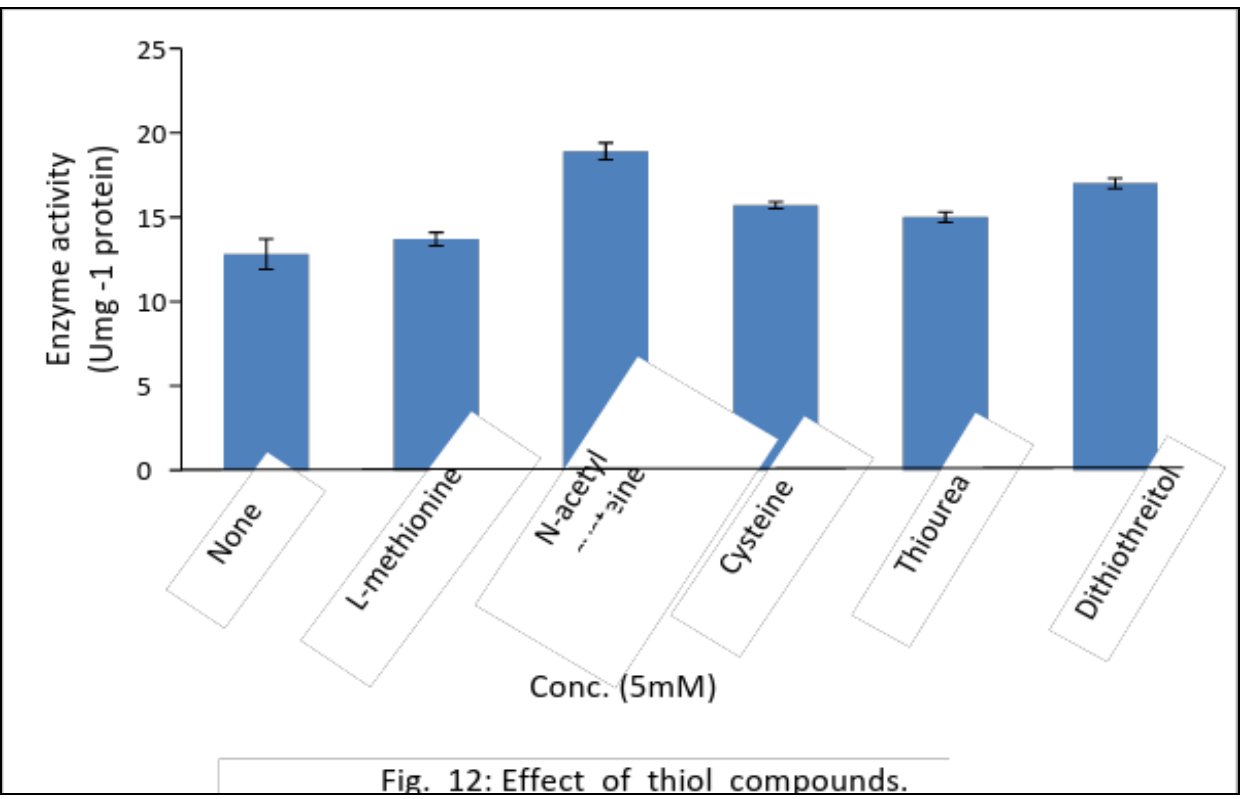


Effect of N-bromosuccinimide (NBS) on Myrosinase Activity

N-bromosuccinimide is a reagent for tryptophanyl residue in enzyme protein (ElShora et al., 2009, El-Shora et al., 2015). Therefore, it was decided in this experiment to test the effect of various concentrations $(1,2,3,4$ and $5 \mathrm{mM})$ of NBS in the reaction mixture. The results in Fig. 7 show that by increasing the concentration of NBS there was a corresponding reduction in the enzyme activity until it reached 1.7 Umg-1 protein at $5 \mathrm{mM}$ and the relative activity was $14.2 \%$ at this concentration. The inhibition of myrosinase by NBS is indicative for the presence of tryptophanyl and this is consistent with the results of Ohtsuru and Hata (1972).

\section{Effect of Phenylglyoxal (PGO) on Myrosinase Activity}

PGO is well known a regent for arginyl group in the enzyme protein (El-Shora et al., 2015). The effect of PGO on myrosinase activity was investigated at various concentrations (1, 2, 3, 4 and $5 \mathrm{mM})$. This compound was added to the reaction mixture. The results in Fig. 8 reveal that the PGO is an inhibitor for myrosinase. The inhibition was dependent on the concentration. The relative activity at $5 \mathrm{mM}$ was 1.8 units $\mathrm{mg}-1$ protein with relative activity of $15.8 \%$. The inhibition of myrosinase by PGO proves that arginyl residue plays important role in enzyme catalysis.

\section{Effect of N-ethylmaleimide (NEM) on Myrosinase Activity}

NEM is a reagent for the sulfhyryl residues in the enzymes protein (El-Shora and AboKassem, 2001). NEM on the enzyme activity was investigated. NEM is used at various concentrations $(1,2,3,4$ and $5 \mathrm{mM})$ in the assay medium. The results in Fig. 9 indicate that the enzyme activity decreased gradually with increasing the concentration of NEM in concentration-dependent manner. The activity of the enzyme was reduced to 4.7 units $\mathrm{mg}-1$ protein at $5 \mathrm{mM}$ with $36.2 \%$ relative activity. These results are consistent with those reported by Durham and Poulton (1990). These results indicate the essentiality of sulfhydryl group for enzyme catalysis.

\section{Effect of Mercaptoethanol on Myrosinase Activity}

The effect of mercaptoethanol on the activity of myrosinase was studied. Mercaptoethanol was tested at various concentrations (20, 40, 60, 80 and $100 \mathrm{mM})$. The results in Fig.10 reveal that mercaptoethanol activated myrosinase in concentration-dependent manner. It was observed that the activity of myrosinase at $100 \mathrm{mM}$ was twice that recorded for the control. Mercaptoethanol as a thiolcompound enhanced other enzymes activity such as protease activity (Kamran et al., 2015). The increase in enzyme activity may indicate that SH- group of the enzyme was protected by mercaptoethanol during the incubation time. Also, it is possible that these thiol compounds may lower the Km of the enzyme to its substrate and thus activating the activity.

\section{Effect of Gibberellic Acid (GA3) on Myrosinase Activity}

The effect of GA3 as phytohormone at various concentrations $(2,4,6,8$ and 10 $\mu \mathrm{mol}$ ) on myrosinase activity was studied. The results obtained are shown in Fig. 11. The results indicate that GA3 was activator for myrosinase and the activation was concentration-dependent. It was noticed that at the highest concentration $(10 \mathrm{mM})$ the enzyme activity was 24.2 units $\mathrm{mg}-1$ protein 
which is twice that of the control value.

Activation of myrosinase by GA3 could be attributed to activation of enzyme molecules in the reaction mixture. GA3 activated other enzymes such as phosphoenolpyruvate carboxylase (Bihzad and El-Shora, 1996), sucrose phosphate synthase (Kaur et al., 2000), NADH-glutamate synthase (ElShora, 2001), acid phosphatase (El-Shora and Metwally, 2009) and cyanide hydratase (El-Shora et al., 2014).

\section{Effect of Other Thiol Compounds on Myrosinase Activity}

In this experiment various thiol compounds including L-methionine, $\mathrm{N}$-acetyl- cysteine, cysteine, thiourea and dithiothreitol were tested regarding their effects on myrosinase activity. These compounds were tested at 5 $\mathrm{mM}$. The results in Fig. 12 show that all the tested compounds were activators for myrosinase. The best activator was $\mathrm{N}$-acetyl cysteine followed by dithiothreitol which exhibited 17 units mg-1 protein. This activity represents nearly one and half of that recorded for the control. Cysteine activated other enzymes such as asparaginase (Warangkar and Khobragade, 2010). Thiourea activated other enzymes such as asparaginase (Warangkar and Khobragade, 2010). Dithiothreitol protects notably enzyme activity loss which occurs by the oxidation of sulfhydryl groups (Alliegro, 2000; El-Shora, 2001; El-Shora and Metwally, 2009). This may indicate that SH- group of the enzyme was protected during the incubation time. Also, it is possible that these thiol compounds may lower the $\mathrm{Km}$ of the enzyme to its substrate and thus activating the activity.

\section{References}

Alliegro, M.C. (2000). Anal. Biochem. Effects of dithiothreitol on protein activity unrelated to thiol-disulfide exchange: for consideration in the analysis of protein function with Cleland's reagent. Anal. Biochem.15: 282:102-6.

Anbu, P., Gopinath, S. C., Cihan, A. C. and Chaulagain, P. B. (2013). Microbial Enzymes and Their Applications in Industries and Medicine. Biomed. Research Inter. http://dx.doi.org/10.1155/2013/204014.

Angelino, D., Dosz, E. B., Sun, J., Hoeflinger, J.L., Van Tassell, M.L., Chen, P., Harnly, J.M., Miller, M.J. and Jeffe, E.H. (2015). Myrosinasedependent and -independent formation and control of isothiocyanate products of glucosinolate hydrolysis. Frontiers in plant Science. Volume 16, doi: 10.3389/fpls.2015.00831.

Bhat, R., Kaur, T., Manu Khajuria, M., Vyas, R., and Vyas , D. (2015). Purification and characterization of a novel redox-regulated isoform of myrosinase ( $\beta$-thioglucoside glucohydrolase) from Lepidium latifolium L. J. Agric. Food Chem., 63: 10218-10226.

Bihzad, M. A. and El-Shora, H. M. (1996). Phosphoenolpyruvate carboxylase from , a C 3-plant. J. Plant Physiol., 149: 669676.

Bradford, M. (1976). A rapid and sensitive method for the quantitation of microgram quantities of protein utilizing the principle of protein-dye binding. Anal. Biochem. 72: 248-254.

Buchholz, K., Kasche, V. and Bornscheuer, U. (2012). Biocatalysts and Enzyme Technology, 2nd Edition. WileyBlackwell.

Cavicchioli, T., Charlton, T., Ertan, H., Mohd Omar, S., Siddiqui, K. and Williams, T. (2011). Biotechnological uses of enzymes from psychrophiles. Microbial Biotechnology, Thematic 
Issue: Extremophiles, 4: 449-460.

Dinkova-Kostova, A. T. and Kostov, R. V. (2012). Glucosinolates and isothiocyanates in health and disease. Trends Mol. Med., 18: 337-347.

Durham, P.L. and Poulton, J.L. (1990). Enzymic properties of purified myrosinase from Lepidium sativum seedlings. Z. Naturforsch. 45: 173- 178.

El-Shora, H. M. ( 2001). Properties and immobilization of urease from leaves of Chenopodium album (C3). Bot. Bull. Acad. Sin., 42: 42: 251-258.

El-Shora, H.M. (2001). Properties and immobilization of urease from leaves of Chenopodium album C3. Bot. Bull. Acad. Sin. (2001) 42: 251-258

El-Shora, H.M. ( 2002). Properties of phenylalanine ammonia -lyase from marrow cotyledons, Plant Sci., 162: 1-7.

El-Shora, H.M. and Abo-Kassem, E.M. (2001). Kinetic characterization of glutamate dehydrogenase of marrow cotyledons. Plant Science, 161:10471057.

El-Shora, H.M, Abou-El-Wafa, G.S. and Amany, H.S. (2015). Purification, thermostability and chemical modification of pullulanase from sunflower. Int. J. Curr. Microbiol. App. Sci. 4: 284-296.

El-Shora, H.M, Khalaf, S.A. and Zaki, O. (2014). Induction, purification and biochemical characteristics of cyanide hydratase from Cladosporium oxysporum. The Ninth Inter. Environmental Conf., Faculty of Science, Zagazig University, Egypt.

El-Shora, H.M, Khalaf, S.A. and Zaki, O. (2015). Active residues and immobilization of cyanide hydratase from Cladosporium oxysporum. Int. J. Adv. Res., 3: 455-465.

El-Shora, H.M. and Metwally, A.M. (2009). Effect of phytohormones and group selective reagents on acid phosphatase from Cladosporium cladosporioides. Asian J. Biotechnol., 1: 1-11.

El-Shora, H.M., Metwally, M.A. and Khlaf, S.A. (2009). Essential groups and stability of $\alpha$-glucosidase of Penicillium notatum. Ann. Microbiol., 9: 285-291.

El-Shora, H.M., Youssef, M. and Khalaf, S.A. (2008). Inducers and inhibitors of laccase from Penicillium. Biotechnology, 7: 35-42.

Fahey, J. W., Wehage, S. L., Holtzclaw, W. D., Kensler, T. W., Egner, P. A., Shapiro, T. A. and Talalay, P. (2012). Protection of humans by plant glucosinolates: efficiency of conversion of glucosinolates to isothiocyanates by the gastrointestinal microflora. Cancer Prev Res (Phila), 5: 603-611.

Gabard, K. A. and Jones, R. L. (1986). Localization of phytase and acid phosphatase isoenzymes in aleurone layers of barley. Physiol. Plant, 67: 182192.

Kaur, S.; Gupta, A. K. and Kaur, N. (2000). Effect of GA3, kinetin and indole acetic acid on carbohydrate metabolism in chickpea seedlings germinating under water stress. Plant Growth Regul., 30: 61-70.

Koroleva, O. A., Gibson, T. M., Cramer, R. and Stain, C. (2010). Glucosinolateaccumulating $\mathrm{S}$-cells in Arabidopsis leaves and flower stalks undergo programmed cell death at early stages of differentiation. Plant J., 64: 456-469.

Li, X., Mosbah M. and Kushad, M. (2005). Purification and characterization of myrosinase from horseradish (Armoracia rusticana) roots. Plant Physiol. Biochem., 43: 503-511.

Mahn, A., Angulo, A. and Cabañas, C. (2014). Purification and characterization of broccoli (Brassica oleracea var. italica) myrosinase ( $\beta$-thioglucosidase glucohydrolase). J. Agric. Food Chem. 62: 11666-11671. 
Mandviwala, T. N. and Khire, J. M (2000). Production of high activity thermostable phytase from thermotolerant Aspergillus niger in solid-state fermentation J. Ind. Microbiol. Biotechnol., 24 : 237-243.

Najafi, M.F.; Deobagkar, D. and Deobagkar, D. (2005). Potential application of protease isolated from Pseudomonas aeruginosa PD100. Electron. J. Biotechnol., 8: 197-203.

Ohtsuru, M., Tsuruo, I. and Hata, T. (1969). Studies on fungous myrosinase. Part II. Effects of various reagents on its enzymatic activities. Agric. Biol. Chem., 33: 1315-1319.

Palmieri, S., Iori, R. and Leoni, O. (1986). Myrosinase from Sinapis alba L.: A new method of purification for glucosinolate analysis. J. Agric. Food Chem., 34: 140-144.

Palop M.L.; Smiths J.P.; Brink B.T. (1995). Degradation of sinigrin by Lactobacillus agilis strain R16. Int. J. Food Microbiol., 26: 219-229.

Prakash, O., Rai, A. K., Singh, J., and Singh, P. M. (2013). Partial purification and kinetic properties of myrosinase from cauliflower (Brassica oleracea var. botrytis). Ind. J. Agri. Biochem., 26: 190-194.

Rakariyatham, N., Butrindr, B., Niamsup, H., and Shank, L. (2005). Screening of filamentous fungi for production of myrosinase. Brazilian J. Microbiol., 36: 242-245.

Sakorn P.; Rakariyatham N.; Niamsup H. and Kovitaya P. (1999). Sinigrin degradation by Aspergillus sp. NR-4201 in liquid culture. Sci. Asia., 25: 189194.

Smiths J.P.; Knol W.; Bol J. Glucosinolate degradation by Aspergillus calvatus and Fusarium oxysporum in liquid and solid-state fermentation. Appl. Microbiol. Biotechnol., 38, 696-701, 1993.

Tani, N., Ohtsuru, M. and Hata, T. (1974). Purification and general characteristics of bacterial myrosinase produced by Enterobacter cloacae. Agric. Biol. Chem., 38: 1623-1630.

Van Doorn, H. E., van der Kruk, G. C., van Holst, G. J., Raaijmakers -Ruijs, C. M., Postma, E., Groeneweg, B. and Jongen, W. H. F. (1998). The glucosinolates sinigrin and progoitrin are important determinants for taste preference and bitterness of Brussels sprouts. F Sci Food Agric., 78: 30-38.

Verkerk, R, Schreiner, M., Krumbein, A., Ciska, E., Holst, B., Rowland, I., et al. (2009). Glucosinolates in Brassica vegetables: the influence of the food supply chain on intake, bioavailability and human health. Mol. Nutr. Food Res. 53(Suppl.

S219.doi:10.1002/mnfr.200800065.

Warangkar, S. C. and Khobragade, C. N. (2010). Purification, characterization and effect of thiol compounds on activity of the Erwinia carotovora LAsparaginase. Enzyme Research, doi.org/10.4061/2010/165878.

\section{How to cite this article:}

Hamed M. El-Shora, Ahmed M. El-Shobaky and Maissa M. El-Atrozy. 2016. Activity of Purified Bacterial Myrosinase and its Essential Residues. Int.J.Curr.Microbiol.App.Sci.5(2): 567-578. doi: http://dx.doi.org/10.20546/ijcmas.2016.502.064 